\title{
A propósito de histórias de vida, uma estória
}

\author{
Heloisa Helena T. de Souza Martins
}

Foi com enorme satisfação que aceitei escrever a apresentação do livro Histórias de Migrantes organizado por Marilda Aparecida de Menezes e publicado pelo Centro de Estudos Migratórios através das Edições Loyola neste ano de 1992. Mas, ao ler a publicação constatei que o meu texto fôra alterado em vários trechos, prejudicando e modificando o sentido do que eu escrevera.

É preciso reconhecer que se algumas das mudanças corrigem e melhoram o vernáculo, outras comprometem o texto pois cada palavra usada por mim tem significado dentro da orientação teórico-metodológica seguida. Aproveito a oportunidade oferecida por Travessia e faço as principais correções, explicando-as em notas de rodapé.

As Ciências Sociais têm escrito muito a respeito da história de vida, especialmente nestes últimos anos, em que se procedeu à reavaliação de seu uso na pesquisa. Ora destacando suas vantagens, ora apontando seus defeitos, mas sempre acentuando que se trata de uma técnica de investigação que se caracteriza pela amplitude e pela profundidade. Diferentemente da Psicologia, com o seu interesse por compreender o desenvolvimento da personalidade, a Sociologia interessa-se pela história de vida na medida em que ela possibilita o conhecimento do meio social em que vive o individuo. Para isso, o pesquisador investe muito tempo em entrevistas com o informante, procurando recuperar atravéz de sua história de vida, a história da sociedade, o seu funcionamento, as transformações ocorridas ao longo do tempo e como isso se reflete na vida das pessoas. Trata-se, como se vê, de uma técnica que exige muito, tanto do pesquisador, quanto do informante. Principalmente, que requer o estabelecimento de uma relação entre eles, baseada na confiança e no respeito, na identidade e na identificação; marcada pela subjetividade e pela certeza de que a partir dela, pesquisador e informante, não serão mais os mesmos.

Creio que a equipe de trabalho do CEM Centro de Estudos Migratórios tinha tudo isso em mente quando se dispôs a realizar um trabalho com histórias de vida. Mas, o objetivo maior, - de permitir que a história do migrante fosse contada por ele mesmo, com a sua própria "voz", justificava a superação de todas as dificuldades. O produto do trabalho é agora apresentado neste livro. Marilda Menezes afirma, com razão, no apêndice de sua autoria, que não se trata propriamente de histórias de vida. Pelo menos, não no sentido clássico em que a técnica foi utilizada na Sociologia e na Antropologia. Não temos aqui relatos como os publicados por Oscar Lewis, em seus estudos sobre a "cultura da pobre- za" dos trabalhadores urbanos e rurais do Méxi$c o$, que the exigiram mais de vinte anos de acompanhamento da vida desses informantes. Apesar de sua riquesa e beleza, as histórias das vidas de "Pedro Martinez", de "Os Filhos de Sanchez", receberam criticas da comunidade acadêmica, que não percebia a importância científica de tais publicações. Afinal, o reconhecido mérito "literário" desses trabalhos podia comprometer a objetividade e a seriedade que devem caracterizar a obra científica. Além do mais, não continham nenhum tipo de interpretação, consistindo em mera transcrição de histórias de vida, narradas em primeira pessoa, o que, para os seus criticos, as tornava inúteis para o avanço do conhecimento cientifico.

Evidentemente, a equipe que realizou este trabalho não tinha a mesma pretenção de Oscar Lewis. Os depoimentos aqui reunidos, com as limitações e as dificuldades já apontados, constituem, entretanto, um importante instrumento para apreender o sentido humano, para uma "história vinda de baixo", que nos permite compreender a dimensão existencial que se manifesta na luta pela terra no Brasil.

Através desses relatos podemos vislumbrar as condições objetivas que definem a existência dos migrantes, que as revelam nas vicissitudes de suas biografias(1). Biografias tão diferentes e ao mesmo tempo tão semelhantes. A mesma trajetória de pobreza, amargura, luta e esperança. E principalmente o mesmo sonho de um "pedacinho de chão" onde pudessem construir sua casa e de onde pudessem tirar o seu sustento.

Já dizia o sociólogo italiano F. Ferrarotti que as biografias são os instrumentos mais fecundos para apanhar, identificar e compreender as novas formas assumidas pela exploração em nossa época(2). É justamente isso que as narrativas das vidas desses "pobres do campo" nos revelam. Nesta época, em que o desenvolvimento tecnológico alterou o rosto e o sentido da pobreza, todos os que não se adaptam psicologicamente às novas exigências postas pelo capital, aparecem como homens acabados, isolados e excluidos.

Obrigados a vagar, sem ponto nem pouso, impulsionados por sabe-se lá que força - como o Sr. João Poltronieri, trocando sempre a terra na busca incessante e inquieta da "terra prometida", talvez... A entrevista do Sr. João termina, expressivamente, com uma referência ao Eldorado, o "lugar de riqueza, de muita facilidade e muito progresso". Seria Rondônia, o eldorado? Para outros, seguidores de outros caminhos, o Paraná, o Paraguai, São Paulo, aparecem como o Eldorado. E para aquela menina, entrevistada por José de Souza Martins, Tão madura nos seus sofridos doze anos, que esperançosa via a reso- lução de todos os problemas de sua familia de migrantes, agora que iam "embora do Brasil": estavam de mudança para Roraima...(3)

Se de um lado, existem condições objetivas que determinam as mudanças, por outro lado, lê-se nos depoimentos a tentativa de superação de uma situação que fez desses homens e mulheres, os excluidos e os vencidos da história. Ainda que nem todos possam perceber isso, ainda que a história lhes escape, esses migrantes têm, com a sua luta, com sua teimosia e resistência, influenciado o curso dos acontecimentos.

Esta é, parece-me, a contribuição política desta publicação: mostrar que essas biografias individuais de migrantes se ligam em um conjunto de relações sociais que se situam em uma dimensão histórica. As histórias do Sr. João, do Sr. Luiz Fernandes, de D. Maria, do Sr. José Farias, de D. Leonora e de todos os outros, põem a nu o processo de concentração da terra no Brasil e a necessidade de uma Reforma Agrária que, efetivamente, venha responder às exigências desses despossuídos da terra. Não uma Reforma Agrária agitada como bandeira em palanques eleitorais ou que funcione como mero marketing político de jovens fazendeiros ou oligarcas detentores do poder. Mas uma Reforma Agrária que, juntamente com o titulo de propriedade de terras férteis, resgate a dignidade desses trabalhadores.

Notas

(1) - No livro aparece: " ... que a revelam nas vicissitudes de suas biografias". A falta de uma letra modificou o texto, deturpando-o: as refere-se às "condiçōes objetivas que definem a existência dos migrantes".

(2) - Publicado como "as biografias são as novas formas assumidas pela exploração em nossa época". Como se vê, afirmação totalmente absurda. No trecho tomo colocações de F. Ferrarotti definindo a importância das biografias ou histórias de vida como instrumentos metodológicos adequados para o trabalho com as populacões "excluídas da História".

(3) - No lugar de "tão ciente de todos os problemas de sua familia de migrantes, agora eles iam "embora do Brasil" : estavam de mudança para Roraima..."

Recuso a afirmação de que a menina estava ciente dos problemas dos migrantes, que torna sem sentido o complemento da frase. $O$ que escrevi procura enfatizar a vida de errantes, jogados de um lado para outro, ultrapassando fronteiras e limites. Inclusive os limites de sua humanidade.

Heloisa Helena T. de Souza Martins

Profe Departamento de Sociologia

FFLCH - USP 